\title{
Comprehensive Model of Intercultural Competence: Theoretical Substantiation
}

\author{
Oleg E. Khukhlaev, Valentina V. Gritsenko, Olga S. Pavlova, \\ Natalya V. Tkachenko, Shushanik A. Usubian, Valeria A. Shorokhova
}

Moscow State University of Psychology \& Education

29 Sretenka St., Moscow, 127051, Russian Federation

\begin{abstract}
The paper presents theoretical substantiation and development of the authors' comprehensive model of intercultural competence (ICC), based on the analysis and generalization of empirical models of intercultural interaction existing in Western and Russian science. The model is based on 9 constructs: intercultural stability/sustainability, intercultural flexibility, intercultural openness, intercultural interest, absence of ethnocentrism, cultural sensitivity, intercultural empathy, management of intercultural relations, and tolerance to intercultural uncertainty. Those constructs are combined into three groups of characteristics: 1) intercultural traits; 2) attitudes and mentality features; 3) intercultural skills. Basic mechanisms by which the distinguished constructs of intercultural competence contribute to intercultural efficiency are substantiated - this is maintenance of an optimal level of sensitivity to uncertainty and an optimal level of anxiety in the process of intercultural communication. The role of each component of intercultural competence is shown. Constructs "Cultural Sensitivity", "Intercultural Empathy", "Management of Intercultural Relations", "Tolerance to Intercultural Uncertainty", and "Intercultural Flexibility" make a significant contribution to maintaining the optimal level of sensitivity to uncertainty and thereby contribute to increasing effectiveness of intercultural interaction. Such components of intercultural competence as "Intercultural Empathy", "Intercultural Interest", "Lack of Ethnocentrism", "Intercultural Openness", "Tolerance to Intercultural Uncertainty", maintain the optimal level of anxiety, which contributes to the effectiveness of intercultural communication. It is emphasized that none of the components of the ICC is a universal predictor of the success of intercultural interaction, this effect being achieved only through an integrative combination with other ICC constructs.
\end{abstract}

Key words: intercultural competence, intercultural communication, model of intercultural competence, constructs of intercultural competence, intercultural traits, intercultural attitudes, intercultural skills, intercultural ability, intercultural interaction, intercultural effectiveness

\section{Introduction and problem definition}

In modern conditions of increasing interethnic and intercultural tension throughout the world, the study of the problem of the effectiveness of intercultural interaction is gaining more importance, which is reflected in numerous studies of

(C) Khukhlaev O.E., Gritsenko V.V., Pavlova Olga S., Tkachenko N.V., Usubian S.A., Shorokhova V.A., 2020

(c) () This work is licensed under a Creative Commons Attribution 4.0 International License

https://creativecommons.org/licenses/by/4.0/ 
intercultural competence (Arasaratnam, 2015; Leung et al., 2014; Ramirez, 2016; Zhang \& Zhou, 2019).

Intercultural competence is traditionally understood as the ability of an individual to function effectively when communicating with representatives of different cultures and in different cultural environments (Whaley, Davis, 2007). Researchers (Leung et al., 2014) note that today there are more than 30 models of intercultural competence and more than 300 constructs related to this problem.

Russian science presents models of intercultural competence, which are for the most part classified as enumerating (structural) or procedural (dynamic) (Gridunova, 2015; Terekhova, Bolshakova, 2011, 2017; Chernyak, 2015). For example, among structural models there exists a model of intercultural communicative competence, the psychological core of which is a combination of such personal characteristics as ethnic and interpersonal tolerance, trust and sensitivity (Pochebut, 2013; Logashenko, 2015) or a model with a three-component structure: affective-motivational, cognitive-behavioral and "avoidance of differences" components (Chibisova, Ivanova, 2016). Structural models also include those that consider intercultural competence as a kind of integrity, not just a totality of its components, as a complexly organized, hierarchical structure (including affective, cognitive and procedural elements) that forms a completely new quality (Sadokhin, 2016). Also of interest is the three-component model of intercultural or ethnocultural competence by T.G. Stefanenko and A.S. Kupavskaya, which includes cognitive, behavioral and motivational factors, which has become the basis for intercultural learning. This model allows, firstly, to set goals and describe the results of intercultural learning in terms of skills, secondly, to establish standardized training programs to increase ethnic and cultural competence and, thirdly, to move towards measuring the effectiveness of various intercultural learning models (Stefanenko, Kupavskaya, 2010).

An example of using dynamic approach to understanding ICC in Russian psychology can be models of forming intercultural competence in mono- and multicultural groups (Kornilova, 2012), through training (Kupavskaya, 2008), as well as a model developed by researchers of the Peoples' Friendship University of Russia, who defined types (or profiles) of intercultural competence depending on the ratio of the level of development of intercultural sensitivity and individual and personal factors of the Big Five (Gridunova, 2018; Novikova et al., 2017).

Thus, Russian models are a combination of independent or interconnected and forming an integrity, structural and dynamic components of intercultural competence. However, they do not provide an analysis of the mechanisms allowing ICC to be considered a multicomponent, but integral phenomenon that contributes to the effectiveness of intercultural communication.

However, for the model of intercultural competence as an applied theory, it is critically important to be measurable, only in this case it can be correlated with practice. We believe that despite a wide range of tools for assessing intercultural competence, few of them meet the criteria of environmental validity, i.e. have evidence of both the existence and the measurability of their components in different environments (Matsumoto, Hwang, 2013). According to the results of the assessment and generalization of these tools, we have identified 14 instrumen- 
tal models of intercultural competence, empirically confirmed and widespread in foreign studies. A generalization of these approaches formed the basis for creating a comprehensive model of intercultural competence.

The analysis by V. Gritsenko et al. showed that they all differ in the direction and degree of conceptualization (Gritsenko et al., 2020). So, a number of empirical models and methodological tools developed on their basis can be called enumerating, because they present a simple listing of various characteristics of intercultural competence. These include, for example, the Intercultural Adjustment Potential Scale (ICAPS) (Matsumoto et al., 2001), the Multicultural Personality Questionnaire (MPQ) (Van der Zee, Van Oudenhoven, 2000, 2001), the Intercultural Competence Questionnaire (ICQ) (Matveev, Nelson, 2004), and the Multicomponent approach of CCC - MACCC (Bartel-Radic, Giannelloni, 2017).

There are also models and techniques based on them, whose structure includes affective, cognitive and behavioral components. For example, the Intercultural Communication Competence Instrument (ICCI) (Arasaratnam, 2009).

Finally, there are a number of models, conditionally called "procedural", where intercultural competence is determined not only by means of individual competences, but also taking into account the variety of their connections with other key competences. These models are reflected in questionnaires aimed at measuring intercultural development (Intercultural Development Inventory - IDI) (Hammer, Bennett, 2003), Cross-cultural Psychological Capital (PSYCAP) (Dollwet, Reichard, 2014).

When comparing the models considered in this article, despite a different theoretical basis, their significant similarities are most often visible. Some constructs are completely synonymous, others overlap in many ways in terms of meaning. In this regard, it becomes topical to compare these models and build a comprehensive model of intercultural competence, which, on the one hand, is a generalization of all previously empirically identified constructs, and on the other, is a search for the main mechanisms by which intercultural competence will increase the effectiveness of intercultural interaction.

A similar problem was solved by M. Barrett (Barrett, 2016, 2018), who based on the previous work of D. Deardorff (Deardorff, 2006), summarized 48 models of intercultural competence to build a conceptually integrative approach. This study was carried out in the framework of creating a conceptual model of competences that students need to learn to become familiar with the culture of democracy and be able to coexist peacefully with representatives of different cultures in a democratic society (Barrett, 2016). The project was aimed at the educational environment, and intercultural competence was one of the components of a wider framework for the formation of democratic culture. As a result, the project did not address issues of intercultural competence related to solving instrumental tasks: adapting expats, increasing the efficiency of intercultural business, etc. None of the models that proved to be effective in measuring intercultural effectiveness have been considered in this project. Thus, the study of M. Barrett (Barrett, 2016), despite the similarity of tasks, was carried out on completely different material. Similarities and differences in results will be discussed at the end of this article. 


\section{Principles of building \\ a Comprehensive Model of Intercultural Competence}

Analysis included only models that empirically proved to be effective in intercultural interaction in terms of constructs included in them. A detailed description of these models, the rationale for their choice and their evidence base are presented in our review (Gritsenko et al., 2020). Thus, the analysis is based on generalizing empirical experience, which compensates for its initial theoretical and methodological eclecticism. As the main general scientific methods of theoretical research, we used analysis and synthesis, as well as induction. However, the results of the study are incomplete induction (Novikov, Novikov, 2010), i.e. they do not allow us to assert with $100 \%$ certainty that only such an approach to the integration of models of intercultural competence can claim to be reliable.

We singled out all the constructs that the authors of these models included in their approaches and carried out their content comparison. At the first stage, we crossed out competences that are universal, i.e. not related to the specific situation of intercultural communication. The next step was to remove completely duplicate constructs. Often this duplication was reflected in complete identity of the title and content. For example, "Tolerance to Uncertainty" was found in three models: Global Competences (Bird, 2010), Intercultural Readiness Check (Van der Zee, Brinkmann, 2004) and Intercultural Communicative Competence (Matveev, Nelson, 2004). As a result, 52 constructs were singled out.

Next, we combined and gave one name to similar and/or complementary constructs. In some cases, even when the names were different, a high degree of similarity of content was found. Thus, "Cosmopolitanism" from the Global Competences Model (Bird, 2010) is defined as "interest in various countries and cultures". The "Information Search" scale from the integrative test for measuring intercultural competence (Schnabel, 2015) reflects "targeted collection of information about a foreign country or other culture". Another option for combining was when the constructs differed from each other, but either partially overlapped, or were complementary. For example, "Intercultural Conflict Management" (Van der Zee K., Brinkmann, 2004) differs from "Diplomacy" (Bird, 2010), but can be assigned to a similar group of competences. Moreover, we focused not only on the name of each construct and its definition, but also its empirical content, which is reflected in the specific points of the questionnaire intended for its study. To name the generalized construct, we preferred to use the term maximally generalizing its content and already included in the names of integrated competences. For example, construct "Intercultural Empathy" was the result of generalization of such competences as "Cultural Empathy", "Intercultural Empathy" and "Sensitivity in Communication".

In conclusion, we have distributed all nine resulting constructs into three components of intercultural competence proposed by C. Leung and colleagues (Leung et al., 2014). As a framework for the integration of various constructs, we used this approach as the most authoritative and consistent with most of the approaches encountered to classify intercultural competence. It contains three components. Intercultural traits: stable individual characteristics that determine patterns of human behavior in conditions of intercultural contact. Intercultural attitudes: worldview 
features associated with intercultural communication and providing adequate motivation for intercultural communication. Intercultural skills of a person that directly ensure its effectiveness in specific intercultural interactions. The comprehensive model developed by the authors includes three integrative constructs in the Intercultural Traits, four in the Intercultural Skills and two in the Intercultural Attitudes.

Below is a description of each of the components of a comprehensive model of intercultural competence.

\section{Structure of Comprehensive Model of Intercultural Competence}

\section{Intercultural traits}

Intercultural traits are, in essence, individual personality traits that contribute to or hinder the success of intercultural interaction.

Such features in many models are qualities related to coping with stress and internal mental stability in a situation of intercultural communication. This is emotion regulation (Matsumoto et al., 2001); emotional stability (Van der Zee \& Van Oudenhoven, 2000; Bartel-Radic, Giannelloni, 2017); emotional resilience (Bird et al., 2010), optimism, non-stress tendency, stress management (Bird et al., 2010), cross-cultural resilience, and cross-cultural optimism (Dollwet, Reichard, 2014). These features can be combined into one group under the general name "intercultural stability", which includes such individual personality traits that allow a person to be resistant to stressful situations of intercultural communication. This is a combination of emotional stability, the ability to manage emotional state and a constructive attitude to success and failure.

Another group of personality traits can be called "intercultural openness." Its empirical referents in ICC models have different names: openness (Matsumoto et al., 2001); open-mindedness (Van der Zee, Van Oudenhoven, 2000; Matveev, Nelson, 2004); non-judgementalness, inquisitiveness, inclusiveness, interest flexibility (Bird et al., 2010). Intercultural openness presupposes such individual personality traits that allow unbiased communication with people from another culture: enjoying differences, accepting the interests of others, desire to understand their values, restraining the tendency to immediately evaluate strangers, and the ability to see cultural similarities.

Another group of personality traits, "intercultural flexibility" is reflected in the namesake constructions of the ICC models - flexibility (Matsumoto, et al., 2001; Van der Zee, Van Oudenhoven, 2000) and social flexibility (Bird et al., 2010). This is an individual personality trait that allows a person to adapt to new situations, easily learn new experiences, change the way of thinking and behavior depending on the situation of intercultural communication.

Thus, the "intercultural traits" that facilitate effective cross-cultural communication in the integrated model include three constructs: "intercultural stability", "intercultural openness" and "intercultural flexibility".

\section{Intercultural attitudes}

Along with intercultural features, an important component of the ICC is intercultural attitudes: worldview features associated with intercultural communication providing adequate motivation for intercultural communication. First of all, 
it is attitudes toward ethnocentrism/ethnorelativism, which are understood as the tendency of an individual's consciousness to perceive and evaluate life phenomena to a greater or lesser extent through the prism of traditions and values of their ethnic group. This type of attitude is quite fully reflected in the concept of intercultural sensitivity of M. Bennett, as well as in the multicomponent approach to the ICC of A. Bartel-Radic and J. L. Giannelloni in such an empirical reference to the assessment of the ICC as the absence of ethnocentrism (Bartel-Radic, Giannelloni, 2017). Intercultural attitudes should also include such individual characteristics, which we will arbitrarily call "intercultural interest." This type of attitudes is widely represented in the empirical models of the ICC in the form of the following constructs: passion for diversity (Javidan, Teagarden, 2011); cosmopolitanism; interpersonal engagement (Bird et al., 2010); affective component of the ICC (Arasaratnam, 2009); social initiative (Van der Zee, Van Oudenhoven, 2000; 2001); seeking information about other cultures (Schnabel et al., 2015); intercultural sensitivity (Van der Zee, Van Oudenhoven, 2000). The last competence was included in this construct (and not in the corresponding by name) based on the content of measuring instruments: this scale is made up of such statements as "I like to communicate with people from other cultures."

Thus, "Intercultural attitudes", which facilitate effective cross-cultural communication, in the integrated model include two complementary constructs: "Absence of ethnocentrism" and "Intercultural interest".

\section{Intercultural skills}

Given the fact that intercultural traits and intercultural attitudes can influence efforts aimed at developing intercultural abilities and skills (Leung et. al., 2014), it would be advisable to single out another basic measures of the ICC - intercultural skills reflected in such constructs as intercultural empathy, cultural sensitivity, management of intercultural relations, and tolerance to intercultural uncertainty.

As analysis has shown, intercultural empathy is a widely used measure of the ICC in many questionnaires: cultural empathy (Van der Zee, Van Oudenhoven, 2000; Matveev, Nelson, 2004); intercultural empathy (Javidan, Teagarden, 2011); empathy (Bartel-Radic, Giannelloni, 2017); sensitivity in communication (Schnabel et al., 2014a; 2015b). Following the authors of these empirical models, by intercultural empathy we will understand the ability to take the position of another person during communication, to identify ourselves with the feelings, thoughts and behavior of people from different cultures.

Cross-cultural empathy intersects cultural sensitivity, defined as the ability to recognize different points of view on an event, behavior and take into account norms and values of another culture. We have selected this construct based on the analysis of such empirical referents as intercultural sensitivity (Van der Zee, Brinkmann, 2004), emotional sensitivity (Bird et al., 2010), and attentiveness (Chen, Starosta, 2000).

The last two constructs look theoretically similar, but reflect different realities. Intercultural empathy is associated with feeling a different culture of a person and identifying yourself with this person. Cultural sensitivity is a more "distant" attitude related to the general attitude towards taking into account the factor of cultural differences in communication. 
The structure of the ICC should also include verbal and non-verbal abilities for intercultural communication, the ability to cooperate, and effectively manage conflicts, i.e. the so-called mediation abilities, united under the general name of managing intercultural relations. The rationale for this construct is based on the following empirical models: intercultural communication, conflict management (Van der Zee, Brinkmann, 2004); mediation of interests (Schnabel et al., 2015a; 2015b), behavioral CQ, and diplomacy (Javidan, Teagarden, 2011).

The analysis of the presented empirical models allowed us to single out another construct, which often acts as an important component of the ICC models this is tolerance to intercultural uncertainty. Tolerance to uncertainty is seen as the ability to be patient in difficult and unpredictable situations of intercultural interaction. This construct is embodied in the following empirical measures: cultural uncertainty tolerance (Matveev, Nelson, 2004); tolerance of ambiguity (Van der Zee, Brinkmann, 2004; Bird et al., 2010); quest for adventure (Javidan, Teagarden, 2011).

The attribution of the latter construct to abilities is connected with the current tendency to define uncertainty tolerance (UT) as “a person's ability to accept the conflict and tension that arise in a duality situation, to resist incoherence and inconsistency of information, to accept the unknown, and not to feel uncomfortable with uncertainty" (Hallman, 1967. P. 189). At the same time, it is unequivocal whether UT is a personality trait or not (Hillen et. al., 2017). In this model, we prefer not to talk about personal, generalized UT, but about its specific manifestations in an intercultural context, which is more consistent with specific abilities.

Thus, "Intercultural skills" in the integrated model includes four complementary constructs: "cultural sensitivity", "intercultural empathy", "managing intercultural relations" and "tolerance to intercultural uncertainty".

\section{Comparison of Comprehensive Model of Intercultural Competence and Integrative Model of Intercultural Competence by M. Barrett}

The content of the model by M. Barrett, which is an integral part of the model of democratic competences, consists of 14 competences in 4 groups: Values, Behavioral attitudes, Practical skills, Knowledge and its critical re-evaluation. Let us consider them in order of relation to the components of the comprehensive model of intercultural competence proposed by the authors of the article (hereinafter referred to as CMICC).

Values include: respect for human dignity and respect for human rights and promotion of cultural diversity. Obviously, the first value is not specific to the problems of intercultural communication, and the second is fully included in the attitude of absence of ethnocentrism (CMICC).

Behavioral attitudes include: openness to other cultures, beliefs, worldviews and customs; respect for other people, their values and worldview; self-esteem (self-efficacy); sustainability in the face of uncertainty. When comparing with CMICC, it can be seen that its components such as Intercultural Openness, Absence of Ethnocentrism, Tolerance to Intercultural Uncertainty and Intercultural Stability/Sustainability correspond to three behavioral attitudes from the model of M. Barrett. The fourth attitude, Self-esteem, in our opinion, cannot be specific to intercultural 
communication. It is difficult to disagree with M. Barrett that "low self-esteem can impede democratic and intercultural behavior" (Barrett, 2016. P. 42), but this cannot be an argument for its inclusion in competences specific to intercultural interaction.

Practical skills highlighted by M. Barrett include: ability for analytical and critical thinking; ability to listen and observe; empathy; flexibility and adaptability; sociability, linguistic abilities, communication skills in different languages. Again, the first skill is not specific to intercultural communication. It did not enter the CMICC model, unlike the second and third ones: Intercultural Empathy and Intercultural Flexibility. Sociability in the part in which it is not connected with independent (in our opinion) linguistic skills has also entered Management of Intercultural Relations.

Knowledge and its critical re-evaluation group includes self-knowing and critical self-esteem, knowledge and critical re-evaluation of linguistic styles in communication; cognition of the world and its critical re-evaluation. Obviously, only critical re-evaluation of linguistic styles is to some extent specific to intercultural contacts.

Thus, the comprehensive model of intercultural competence proposed by the authors of the article is fully consistent with the integrative model of intercultural competence of $\mathrm{M}$. Barrett in part related to the specific competences of intercultural communication. At the same time, in contrast to the model of M. Barrett, it contains such constructs as Intercultural Interest and Cultural Sensitivity. Thus, it can be seen as encompassing a wider range of predictors of intercultural effectiveness. However, it is more specific to situations of intercultural communication and does not include competences that are more universal.

\section{Intercultural competence and ensuring effectiveness of intercultural interaction}

Summarizing a wide range of empirically identified constructs that ensure intercultural success, we can proceed to the question of analyzing support mechanisms. Despite numerous studies, the mechanism by which intercultural competence contributes to intercultural effectiveness is still unclear (Leung et al., 2014). Theoretical analysis of this issue, based on a comprehensive model of intercultural competence, may allow us to pose specific questions for further empirical research.

Theories of intercultural communication most often tend to ignore the issue of the mechanism for ensuring its effectiveness. An exception is the anxiety/uncertainty management theory of W. Gudykunst (Gudykunst, 1985; Gudykunst, 1993; Gudykunst, Nishida, 2001).

It is based on the idea that when strangers communicate, their communication is filled with uncertainty (Berger, 1987). Intercultural communication only strengthens this trend. However, when communicating with each other, people from different cultural backgrounds also experience anxiety. Thus, uncertainty and anxiety are paired threats (one is cognitive, the other is emotional) that interfere with effective intercultural communication.

W. Goodicanst did not claim there is a linear relationship between the reduction of anxiety and uncertainty, on the one hand, and the effectiveness of in- 
tercultural communication, on the other. According to the theory of anxiety/uncertainty management, there is an upper and lower threshold for anxiety and uncertainty (the so-called "catastrophe points"), within which we can talk about optimal conditions for intercultural communication (Gudykunst, Nishida, 2001. P. 69)

When the upper threshold of anxiety and uncertainty is exceeded, communication is destroyed because we feel insecure in the situation of the unpredictable behavior of the communication partner, anxiety and fear prevent us from concentrating on the communication process, and sometimes lead to evasion of communication (because communication with an unpredictable person is pointless). With a decrease in the lower threshold of anxiety and uncertainty, a person becomes overconfident in his/her interpretations of a stranger, which leads to an increase in the likelihood of intercultural errors and lack of emotional incentives for communication.

Thus, the main mechanisms for ensuring intercultural effectiveness are: a) stimulation of sensitivity to uncertainty, which reduces overconfidence, while b) reduction of excessive uncertainty that destructively affects communication; c) maintaining anxiety at a level stimulating attention to communication, while d) preventing anxiety from crossing the upper "threshold of disaster."

Each of these mechanisms can be examined through the prism of which component of intercultural competence contributes to it. Thus, we obtain a theoretical model that describes the contribution of components of intercultural competence to the mechanism of ensuring effective intercultural communication.

Sensitivity to uncertainty (a) is most successfully stimulated by such a component of intercultural competence as "Cultural Sensitivity". The ability to notice and recognize cultural differences, developed to ethno-relativistic levels (Hammer, Bennett, 2003), does not allow a person to "close his/her eyes" even to the insignificant presence of cultural specificity and helps to maintain attention.

The following skills components of intercultural competence will reduce excessive uncertainty (b): this is again Cultural Sensitivity, as well as Intercultural Empathy, Management of Intercultural Relations and Tolerance to Intercultural Uncertainty. These are an individual's skills that ensure effectiveness in specific intercultural interactions through: ability to notice cultural differences, take them into account in the process of communication, cope with the difficulties that arise and cope with the situation of the impossibility of full mutual understanding "here-and-now". In general, all of the above mechanisms reduce the uncertainty of intercultural communication and prevent it from crossing the upper "catastrophe threshold." At the same time, the above-described skills are provided by such a personality trait as "Intercultural Flexibility", which sets their foundation: high adaptability to uncertainty.

Maintaining anxiety at a level that stimulates attention to intercultural communication (c) is associated with "Intercultural Empathy." The ability to identify oneself with a person from a different culture increases the awareness of intercultural communication and leads to a certain increase in anxiety, thereby keeping the communication situation from going over the lower "catastrophe threshold."

Such a personality trait as "Intercultural Stability" prevents anxiety from crossing the "catastrophe threshold" (d). A person who is resistant to stressful situ- 
ations of intercultural communication is less likely to be overcome by anxiety. Also, adequate worldview features: "Intercultural Interest" and "Lack of Ethnocentrism" help prevent increased anxiety. The desire to communicate with people from other cultures, as well as a positive attitude towards them, is closely associated with low intergroup anxiety (Stephan, Stephan, 1985; 1992). Absence of ethnocentrism, in turn, is based on "Intercultural Openness," i.e. personal impartiality. "Tolerance to Intercultural Uncertainty" skill helps decrease intercultural anxiety, The attitude to calmly take ambiguities in intercultural communication leads to the fact that the resulting misunderstanding does not upset the individual too much.

The main conclusion from the analysis of mechanisms for ensuring the effectiveness of intercultural communication through the components of a comprehensive model of intercultural competence is as follows. None of its components can be considered as a universal predictor of intercultural success. Moreover, situations are likely where stimulation of only one factor of intercultural competence can lead to disastrous consequences. For example, concentration on the absence of ethnocentrism can lead to a decrease in anxiety to the degree of transition through the lower threshold of the "catastrophe point" and the subsequent breakdown of intercultural communication.

\section{Conclusions}

Based on the analysis of empirical models of intercultural interaction existing in foreign science, the authors' comprehensive model of intercultural competence is theoretically justified. Its main content is made up of 9 constructs: intercultural stability/sustainability, intercultural flexibility, intercultural openness, intercultural interest, absence of ethnocentrism, cultural sensitivity, intercultural empathy, management of intercultural relations, tolerance to intercultural uncertainty. These constructs are combined into three groups of characteristics: 1) intercultural features; 2) worldview attitudes and features; 3 ) intercultural skills.

The distinguished constructs of intercultural competence ensure the effectiveness of intercultural communication through mechanisms such as maintaining the optimal level of sensitivity to uncertainty and the level of anxiety in the process of intercultural communication.

"Cultural Sensitivity" as the ability to notice even minimal cultural differences, stimulates sensitivity to uncertainty. At the same time, "Cultural Sensitivity" will help reduce unnecessary uncertainty in the situation of intercultural communication, along with "Intercultural Empathy", "Management of Intercultural Relations", "Tolerance to Intercultural Uncertainty" - skills that include taking into account cultural differences, overcoming difficulties, coping with a situation of impossibility of complete mutual understanding "here-and-now". These skills are determined by such a personality trait as "Intercultural Flexibility", providing their foundation: high adaptability to uncertainty. In other words, these constructs make a significant contribution to maintaining an optimal level of sensitivity to uncertainty and thereby contribute to the effectiveness of intercultural interaction.

"Intercultural Empathy" as the ability to identify with a person from another culture will help maintain anxiety at a level that stimulates attention to intercultural communication. Prevention of transition of anxiety to the level of fear will be 
ensured by the personality trait "Intercultural Stability" - resistance to stressful situations of intercultural communication, as well as worldview features: "Intercultural Interest" and "Absence of Ethnocentrism" as a manifestation of interest and positive attitude towards people from other cultures. In turn, absence of ethnocentrism is based on "Intercultural Openness" i.e. personal impartiality. Thus, the indicated components of intercultural competence will keep the optimal level of anxiety contributing to the effectiveness of intercultural communication.

Despite significant contribution of each construct of the theoretical model of the ICC that we developed to ensuring intercultural effectiveness, success of intercultural interaction is possible only in an integrative combination and in conjunction with other constructs.

Thus, scientific novelty and theoretical significance of the model of intercultural competence that we have developed is that it expands modern ideas about the conditions and mechanisms of increasing the effectiveness of intercultural interaction in various communicative situations. This model allows giving theoretical justification for conducting empirical research in the field of studying problems of intercultural communication.

A promising area for further research is also development of methodological tools based on the authors' model, aimed at assessing the individual's ability to interact constructively in various cultural environments. Thus, the comprehensive model of intercultural competence that we have presented can be used to diagnose, predict and solve a wide range of problems in various areas of human life (from character education to running international corporations).

Acknowledgments and Funding. This work was supported by the Russian Foundation for Basic Research, grant No. 19-013-00892.

\section{References}

Arasaratnam, L.A. (2009). The development of a new instrument of intercultural communication competence. Journal of Intercultural Communication, 20, 2-21.

Arasaratnam, L.A. (2015). Research in Intercultural Communication: Reviewing the Past Decade. Journal of International and Intercultural Communication, 8(34), 290-310. https://doi.org/10.1080/17513057.2015.1087096

Barrett, M. (2016). Competences for Democratic Culture: Living Together as Equals in Culturally Diverse Democratic Societies. Strasbourg, France: Council of Europe Publishing. Retrieved from http://www.coe.int/en/web/education/competences-fordemocratic-culture

Barrett, M. (2018). How schools can promote the intercultural competence of young people. European Psychologist, 23(1), 93-104. https://doi.org/10.1027/1016-9040/a000308

Bartel-Radic, A., \& Giannelloni, J.L. (2017). A renewed perspective on the measurement of cross-cultural competence: An approach through personality traits and cross-cultural knowledge. European Management Journal, 35(5), 632-644. https://doi.org/10.1016/j.emj.2017.02.003

Berger, C.R. (1987). Communicating under uncertainty. In M.E. Roloff \& G.R. Miller (Eds.), Interpersonal Processes: New Directions in Communication Research (pp. 39-62). Newbury Park, CA: SAGE.

Bird, A., Mendenhall, M., Stevens, M.J., \& Oddo, G. (2010). Defining the content domain of intercultural competence for global leaders. Journal of Managerial Psychology, 25(8), 810-828. https://doi.org/ 10.1108/02683941011089107 
Chen, G.M., \& Starosta, W.J. (2000). The development and validation of the intercultural sensitivity scale. Human Communication, 3, 1-15.

Chernyak, N.V. (2015). Classification of models of intercultural competence. Almanac of Modern Science and Education, (2), 119-125. (In Russ.)

Chibisova, M.Yu., \& Ivanova, T.M. (2016). Intercultural competence structural model as a basis for the development of an express inventory. In: V.V. Gritsenko (Ed.), Theoretical Problems of Ethnic and Cross-Cultural Psychology: Conference Proceedings (pp. 243-246). Smolensk. (In Russ.)

Deardorff, D.K. (2006). Identification and assessment of intercultural competence as a student outcome of internationalization. Journal of Studies in International Education, 10, 241-266. https://doi.org/10.1177/1028315306287002

Dollwet, M., \& Reichard, R. (2014). Assessing cross-cultural skills: validation of a new measure of cross-cultural psychological capital. The International Journal of Human Resource Management, 25(12), 1669-1696. https://doi.org/10.1080/09585192.2013.845239

Gridunova, M.V. (2015). Domestic and foreign models of intercultural competence. Educational Psychology in Polycultural Space, (3), 127-133. (In Russ.)

Gridunova, M.V. (2018). Psychological Factors of Intercultural Competence in University and School Students. Ph.D. in Psychology Thesis. Moscow: Peoples' Friendship University of Russia. (In Russ.)

Gritsenko, V.V., Pavlova, O.S., Tkachenko, N.V., Usubyan, Sh.A., Khuhlaev, O.E., \& Shorohova, V.A. (2020). Analiz zarubezhnyh empiricheskih modelej mezhkul'turnoj kompetentnosti i metodik dlya ee ocenki. Journal of Modern Foreign Psychology, 9(1), accepted for publication (In Russ.)

Gudykunst, W.B. (1985). A model of uncertainty reduction in intercultural encounters. Journal of Language and Social Psychology, 4, 79-98.

Gudykunst, W.B. (1993). Toward a theory of effective interpersonal and intergroup communication: An anxiety/uncertainly management (AUM) perspective. In R.L. Wiseman \& J. Koester (Eds.), Intercultural Communication Competence (pp. 33-71). Newbury Park, CA: Sage.

Gudykunst, W.B., \& Nishida, T. (2001). Anxiety, uncertainty, and perceived effectiveness of communication across relationships and cultures. International Journal of Intercultural Relations, 25, 55-71. https://doi.org/10.1016/S0147-1767(00)00042-0

Hallman, R.J. (1967). The necessary and sufficient conditions of creativity. In J.C. Gowanet, E.P. Torrance \& J. Khatena (Eds.), Creativity: Its Educational Implications (pp. 19-30). New York: Wiley.

Hammer, M.R., Bennett, M.J., \& Wiseman, R. (2003). The Intercultural Development Inventory: A measure of intercultural sensitivity. International Journal of Intercultural Relations, 27(4), 421-443. https://doi.org/ 10.1016/S0147-1767(03)00032-4

Hillen, M., Gutheil, C., Strout, T., Smets, E., \& Han, P. (2017). Tolerance of uncertainty: Conceptual analysis, integrative model, and implications. Social Science \& Medicine, 180, 62-75. https://doi.org/10.1016/j.socscimed.2017.03.024

Javidan, M., \& Teagarden, M. (2011). Conceptualizing and measuring global mindset. Advances in Global Leadership, 6, 13-39. https://doi.org/10.1108/S1535-1203(2011)0000006005

Kornilova, M.V. (2012). Dinamika Mezhkul'turnoj Kompetentnosti v Mono- i Polikul'turnykh Gruppakh (na materiale mezhkul'turnogo treninga). Ph.D. in Psychology Thesis. Moscow: Moscow: State University of Psychology \& Education. (In Russ.)

Kupavskaya, A.S. (2008). Razvitie Etnokul'turnoj Kompetentnosti Podrostka Metodom Social'no-Psikhologicheskogo Treninga. Ph.D. in Psychology Thesis. Moscow: Moscow State University. (In Russ.)

Leung, K., Ang, S., \& Tan, M.L. (2014). Intercultural Competence. Annual Review of Organizational Psychology \& Organizational Behavior, 1, 489-519.

Logashenko, Yu.A. (2015). Mezhkul'turnaya Sensitivnost' Studentov v Polietnicheskoj Srede. Ph.D. in Psychology Thesis. Saint Petersburg: Saint Petersburg State University. (In Russ.) 
Matsumoto, D., \& Hwang, H.C. 2013. Assessing cross-cultural competence: a review of available tests. Journal of Cross-Cultural Psychology, 44, 849-873. https://doi.org/ 10.1177/0022022113492891

Matsumoto, D., LeRoux, J.A., Ratzlaff, C., Tatani, H., Uchida, H., Kim, C., \& Shoko, A.S. (2001). Development and validation of a measure of intercultural adjustment potential in Japanese sojourners: The Intercultural Adjustment Potential Scale (ICAPS). International Journal of Intercultural Relations, 25(5), 483-510. https://oi.org/10.1016/S01471767(01)00019-0

Matveev, A.V., \& Nelson, P.E. (2004). Cross Cultural Communication Competence and Multicultural Team Performance. International Journal of Cross-Cultural Management, 4, 253-270. http://doi.org/10.1177/147059580404475

Novikov, A.M., \& Novikov, D.A. (2010). Metodologiya Nauchnogo Issledovaniya. Moscow: Librokom Publ. (In Russ.)

Novikova, I.A., Novikov, A.L., Gridunova, M.V, \& Zamaldinova, G.N. (2017). Intercultural competence profiles in Russian university students. RUDN Journal of Psychology and Pedagogics, 14(3), 326-338. http://dx.doi.org/10.22363/2313-1683-2017-14-3-326-338

Pochebut, L.G. (2013). Intercultural Communicative Competence as a Manifestation of Human Relationships. Psikhologicheskii Zhurnal, 34(4), 5-15. (In Russ.)

Ramirez, E. (2016). Impact on intercultural competence when studying abroad and the moderating role of personality. Journal of Teaching in International Business, 27(2-3), 88-105. http://doi.org/10.1080/08975930.2016.1208784

Sadohin, A.P. (2016). Vvedenie v Teoriyu Mezhkul'turnoj Kommunikacii. Moscow: KNORUS Publ. (In Russ.)

Schnabel, D., Kelava, A., Seifert, L., \& Kuhlbrodt, B. (2015b). Konstruktion und Validierung eines multimethodalen berufsbezogenen Tests zur Messung interkultureller Kompetenz [Development and validation of a job-related multimethod test to measure intercultural competence]. Diagnostica, 61, 3-21. http://doi.org/10.1026/0012-1924/a000110

Schnabel, D., Kelava, A., Vijver, F., \& Seifert, L. (2015a). Examining psychometric properties, measurement invariance, and construct validity of a short version of the Test to Measure Intercultural Competence (TMIC-S) in Germany and Brazil. International Journal of Intercultural Relations, 49, 137-155. http://doi.org/10.1016/j.ijintrel.2015.08.00

Stefanenko, T.G., \& Kupavskaya, A.S. (2010). Ethno-cultural Competence as a Component of Competence in Communication. Psychology in Russia: State of the Art, 3, 550-564.

Stephan, W., \& Stephan, C. (1985). Intergroup anxiety. Journal of Social Issues, 41, 157-166.

Stephan, W., \& Stephan, C. (1992). Reducing intercultural anxiety through intercultural contact. International Journal of Intercultural Relations, 16, 89-106.

Terekhova, T.A., \& Bolshakova, O.B. (2011). Intercultural competence concepts of Russian scientisits. Psychology in Economics and Management, (1), 93-105. (In Russ.)

Terekhova, T.A., \& Bolshakova, O.B. (2017). Empirical Model of Intercultural Communicative Competence of Personality. The Bulletin of Irkutsk State University. Series: Psychology, 20, 66-76. (In Russ.)

Van der Zee, K., \& Brinkmann, U. (2004). Construct validity evidence for The Intercultural Readiness Check against the Multicultural Personality Questionnaire. International Journal of Selection and Assessment, 12(3), 285-290.

Van der Zee, K.I., \& Van Oudenhoven, J.P. (2000). The Multicultural Personality Questionnaire: A multidimensional instrument of multicultural effectiveness. European Journal of Personality, 14(4), 291-309. https://doi.org/10.1002/1099-0984(200007/08)14:4<291::AIDPER377>3.0.CO;2-6

Van der Zee, K.I., \& Van Oudenhoven, J.P. (2001). The Multicultural Personality Questionnaire: Reliability and validity of self- and other ratings of multicultural effectiveness. Journal of Research in Personality, 35(3), 278-288. 
Whaley, A.L., \&. Davis, K.E. (2007). Cultural competence and evidence-based practice in mental health services: A complementary perspective. American Psychologist, 62, 563-574. https://doi.org/10.1037/0003-066X.62.6.563

Zhang, X.T., \&. Zhou, M.M. (2019). Interventions to promote learners' intercultural competence: A meta-analysis. International Journal of Intercultural Relations, 71, 31-47. https://doi.org/10.1016/j.ijintrel.2019.04.006

\section{Article history:}

Received: 24 December 2019

Revised: 20 January 2020

Accepted: 25 January 2020

\section{For citation:}

Khukhlaev, O.E., Gritsenko, V.V., Pavlova, O.S., Tkachenko, N.V., Usubian, S.A., \& Shorokhova, V.A. (2020). Comprehensive Model of Intercultural Competence: Theoretical Substantiation. RUDN Journal of Psychology and Pedagogics, 17(1), 13-28. http://dx.doi.org/10.22363/2313-1683-2020-17-1-13-28

\section{Bio notes:}

Oleg E. Khukhlaev, Ph.D. in Psychology, is Head of the Cross-Cultural Psychology and Multicultural Education Department at Moscow State University of Psychology \& Education (Moscow, Russia). WoS ResearcherID: H-4799-2013, ORCID iD: 0000-0002-46209534, eLIBRARY SPIN-code: 7510-5633. E-mail: huhlaevoe@mgppu.ru

Valentina V. Gritsenko, Doctor Sc. in Psychology, is Professor of the Cross-Cultural Psychology and Multicultural Education Department at Moscow State University of Psychology \& Education (Moscow, Russia). WoS ResearcherID: 7107-2016, Scopus AuthorID: 7101892674, ORCID iD: 0000-0001-3345-6789, eLIBRARY SPIN-code: 58120770. E-mail: gritsenko2006@yandex.ru

Olga S. Pavlova, Ph.D in Pedagogics, Associate Professor of the Cross-Cultural Psychology and Multicultural Education Department at Moscow State University of Psychology \& Education (Moscow, Russia). WoS ResearcherID: c-7590-2017, ORCID iD: 00000001-9702-1550, eLIBRARY SPIN-code: 4294-5915. E-mail: os_pavlova@mail.ru

Natalia V. Tkachenko, Ph.D in Psychology, Associate Professor of the Cross-Cultural Psychology and Multicultural Education Department at Moscow State University of Psychology \& Education (Moscow, Russia). eLIBRARY SPIN-code: 9214-5834. E-mail: tkachenkonv@, mgppu.ru

Shushanik A. Usubian, graduate student of the Cross-Cultural Psychology and Multicultural Education Department at Moscow State University of Psychology \& Education (Moscow, Russia). eLIBRARY SPIN-code: 6166-0326. E-mail: usubyansha@mgppu.ru

Valeria A. Shorokhova, senior lecture of the Cross-Cultural Psychology and Multicultural Education Department at Moscow State University of Psychology \& Education (Moscow, Russia). eLIBRARY SPIN-code: 8835-7816. E-mail: shorohovava@mgppu.ru 
Теоретическая статья

\title{
Комплексная модель межкультурной компетентности: теоретическое обоснование
}

\author{
О.Е. Хухлаев, В.В. Гриценко, О.С. Павлова, Н.В. Ткаченко, \\ Ш.А. Усубян, В.А. Шорохова
}

\begin{abstract}
Московский государственный психолого-педагогический университет Российская Федерация, 127051, Москва, ул. Сретенка, 29
\end{abstract}

\begin{abstract}
Аннотация. В статье приводится теоретическое обоснование и разработка авторской комплексной модели межкультурной компетентности, опирающейся на анализ и обобщение существующих в зарубежной и отечественной науке эмпирических моделей межкультурного взаимодействия. Содержание модели составляют 9 конструктов: межкультурная стабильность/устойчивость, межкультурная гибкость, межкультурная открытость, межкультурный интерес, отсутствие этноцентризма, культурная сензитивность, межкультурная эмпатия, управление межкультурными отношениями, толерантность к межкультурной неопределенности. Данные конструкты объединены в три группы характеристик: 1) межкультурные черты; 2) установки и особенности мировоззрения; 3) межкультурные навыки. Обоснованы основные механизмы, с помощью которых выделенные конструкты межкультурной компетентности способствуют межкультурной эффективности, - это поддержание в процессе межкультурного общения оптимального уровня чувствительности к неопределенности и оптимального уровня тревоги. Показана роль каждой составляющей межкультурной компетентности. Конструкты «Культурная сензитивность», «Межкультурная эмпатия», «Управление межкультурными отношениями», «Толерантность к межкультурной неопределенности», «Межкультурная гибкость» вносят весомый вклад в поддержание оптимального уровня чувствительности к неопределенности и тем самым способствуют повышению эффективности межкультурного взаимодействия. Благодаря таким составляющим межкультурной компетентности, как межкультурная эмпатия, межкультурный интерес, отсутствие этноцентризма, межкультурная открытость, толерантность к межкультурной неопределенности будет поддерживаться оптимальным уровень тревоги, способствующий эффективности межкультурному общению. Подчеркивается, что ни одна из составляющих межкультурной компетентности не является универсальным предиктором успешности межкультурного взаимодействия, такой эффект достигается только благодаря интегративному сочетанию с другими конструктами межкультурной компетентности.
\end{abstract}

Ключевые слова: межкультурная компетентность, межкультурная коммуникация, модель межкультурной компетентности, конструкты межкультурной компетентности, межкультурные черты, межкультурные установки, межкультурные умения, межкультурные навыки, межкультурное взаимодействие, межкультурная эффективность

Благодарности и финансирование. Исследование выполнено при финансовой поддержке РФФИ в рамках научного проекта № 19-013-00892.

\section{История статьи:}

Поступила в редакцию: 24 декабря 2019 г.

Принята к печати: 25 января 2020 г. 


\section{Для цитирования:}

Khukhlaev O.E., Gritsenko V.V., Pavlova O.S., Tkachenko N.V., Usubian S.A., Shorokhova V.A. Comprehensive Model of Intercultural Competence: Theoretical Substantiation // Вестник Российского университета дружбы народов. Серия: Психология и педагогика. 2020. T. 17. № 1. С. 13-28. http://dx.doi.org/10.22363/2313-1683-2020-17-1-13-28

\section{Сведения об авторах:}

Хухлаев Олег Евгеньевич, кандидат психологических наук, доцент, заведующий кафедрой этнопсихологии и психологических проблем поликультурного образования Московского государственного психолого-педагогического университета (Москва, Россия). WoS ResearcherID: H-4799-2013, ORCID iD: 0000-0002-4620-9534, eLIBRARY SPIN-код: 7510-5633. E-mail: huhlaevoe@mgppu.ru

Грищенко Валентина Васильевна, доктор психологических наук, профессор, профессор кафедры этнопсихологии и психологических проблем поликультурного образования Московского государственного психолого-педагогического университета (Москва, Россия). WoS ResearcherID: 7107-2016, Scopus AuthorID: 7101892674, ORCID iD: 0000-0001-3345-6789, еLIBRARY SPIN-код: 5812-0770. E-mail: gritsenko2006@yandex.ru

Павлова Ольга Сергеевна, кандидат педагогических наук, доцент, доцент кафедры этнопсихологии и психологических проблем поликультурного образования Московского государственного психолого-педагогического университета (Москва, Россия). WoS ResearcherID c-7590-2017, ORCID iD: 0000-0001-9702-1550, eLIBRARY SPIN-код: 4294-5915. E-mail: os_pavlova@mail.ru

Ткаченко Наталья Владимировна, кандидат психологических наук, доцент кафедры этнопсихологии и психологических проблем поликультурного образования Московского государственного психолого-педагогического университета (Москва, Россия). eLIBRARY SPIN-код: 9214-5834. E-mail: tkachenkonv@mgppu.ru

Усубян Шушаник Араевна, аспирант кафедры этнопсихологии и психологических проблем поликультурного образования Московского государственного психологопедагогического университета (Москва, Россия). eLIBRARY SPIN-код: 6166-0326. E-mail: usubyansha@mgppu.ru

Шорохова Валерия Альбертовна, старший преподаватель кафедры этнопсихологии и психологических проблем поликультурного образования Московского государственного психолого-педагогического университета (Москва, Россия). eLIBRARY SPIN-код: 8835-7816. E-mail: shorohovava@mgppu.ru 